\title{
Biomonitoring Air Pollution Using Moss in Georgia
}

\author{
Shamil Shetekauri ${ }^{1}$, Omari Chaligava ${ }^{1}$, Tolkha Shetekauri ${ }^{1}$, Ana Kvlividze ${ }^{1}$, \\ Tamaz Kalabegishvili ${ }^{2}$, Elene Kirkesali², Marina Vladimirovna Frontasyeva ${ }^{3 *}$, \\ Olesya Evgenievna Chepurchenko ${ }^{3}$, Vladimir Anatolievich Tselmovich ${ }^{4}$
}

\author{
${ }^{1}$ I. Javakhishvili Tbilisi State University, Tbilisi, Georgia \\ ${ }^{2}$ I. Javakhishvili Tbilisi State University, E. Andronikashvili Institute of Physics, Tbilisi, Georgia \\ ${ }^{3}$ Joint Institute for Nuclear Research, Moscow Region, Russian Federation \\ ${ }^{4}$ Geophysical Observatory Borok, Schmidt Institute of Physics of the Earth of the Russian Academy of Sciences, \\ Yaroslavl Region, Russian Federation
}

Received: 23 March 2017

Accepted: 15 May 2017

\begin{abstract}
The results of atmospheric deposition of trace elements in a 2015 moss survey in Georgia are reported. The 36 moss samples were collected in different regions of the Caucasus in compliance with the UNECE ICP Vegetation guidelines. Elemental determination was carried out by epithermal neutron activation analysis (ENAA). For the first time, 47 elements were determined for the sampled areas. The scanning electron microscopy with $\mathrm{x}$-ray energy-dispersive analysis was applied to examine the origin of atmospheric particles accumulated by mosses. Microanalysis of moss samples collected in the highlands of Georgia showed the presence of clastic, anthropogenic, and cosmic dust particles. Comparison of the determined values with corresponding data from a pristine area of Norway was carried out. Multivariate statistical analysis of the results obtained was used to identify and characterize pollution sources in the sampled areas of Georgia. Elevated levels of heavy metals were revealed in Western Georgia, where many industrial mining enterprises and high-traffic roads are located.
\end{abstract}

Keywords: Georgia, moss biomonitoring, heavy metals, neutron activation analysis, scanning electron microscopy

\section{Introduction}

Since 2014 Georgia has participated in the moss biomonotoring program of UNECE ICP Vegetation in the framework of the Convention on Long-Range Transboundary Air Pollution in Europe (CLRTAP) [1]. Presently a wide range of atmospheric quality

*e-mail: marina@nf.jinr.ru monitoring methods exists. One of these directions is the study of atmospheric deposition of heavy metals by means of moss biomonitors. The most commonly used moss species in air pollution biomonitoring are Hylocomium splendens (Hedw.) (Schimp.), Pleurozium schreberi (Mitt.) (Brid.), and Hypnum cupressiforme (Hedw.) [2-4].

Georgia is a mountainous country in the Caucasus with specific geographic conditions and climate, characterized by high-level anthropogenic pollution 
in some districts, namely Lower Svaneti, Kutaisi, Zestafoni, and others [5-9]. In 2014 a preliminary collection of Georgian moss (16 samples from different sites around the country) was investigated in collaboration with JINR [10]. It was the first time for the western Caucasus, when the moss biomonitoring method of atmospheric deposition of trace elements was used. The investigation showed that this method is an efficient technique for studying the environmental situation in a country with a unique geographical location. In 2015 the research was continued and moss samples were collected on a larger territory of Georgia.

\section{Materials and Methods}

\section{Study Area and Sampling}

The sampling of the 2015 collection was carried out according to the standard procedure described in the Moss Manual of the ICP Vegetation 2015 [11]. The vertical altitudes of sampling range of $161 \mathrm{~m}$ to 2,052 $\mathrm{m}$ a.s.l. Seventeen samples were taken in southern Georgia (mostly from Meskheti). The climate in this part of Georgia is mild and moderately humid. Eight samples were collected from eastern Georgia, the majority from Khevsureti. The climate in this mountain region is cold and temperate. Sample Nos. 18 and 19 were taken near Stepantsminda in Dariali gorge, near a Georgian Military Road. Seven samples were taken from northwestern Georgia, mainly from Svaneti. Here several areas are contaminated by arsenic extraction, which was performed until 1990 (Ailama, Koruldashi). The landscape of this region is dominated by mountains and deep gorges that separate them. Two samples were taken in western Georgia in Imereti. One was taken near Rikoti Pass, which passes a highway that connects two main cities of Georgia (Tbilisi and Kutaisi), and the other one is not far from Kutaisi. The main environmental pollution sources in sampled regions are transportation, mining of manganese, metallurgy, machinery, human waste, and burials of old industrial waste from Soviet times [5-9].

A total of 36 samples of three moss species (Hylocomium splendens (Hedw.) (Schimp.) - 13, Pleurozium schreberi (Mitt.) (Brid.) - 8, and Hypnum cupressiforme (Hedw.) - 15) growing on organic top-soils in forests, covering foothills, subalpine, and alpine belts and other natural environments were collected during summer 2015. For each sampling site no fewer than 10 sub-samples were taken in the area of 50 × $50 \mathrm{~m}$ and combined into one collective sample. Descriptions of all sites have been recorded along with geographical coordinates determined by GPS. The sampling map is shown in Fig. 1.

\section{Sample Preparation}

\section{$N A A$}

The preparation of samples for NAA was performed in the chemical laboratory. Only the green and greenbrown shoots from the last three years' growth were taken for analysis. Each sample was cleaned from extraneous materials like soil particles, leaves, needles, etc. To prevent contamination of the material we used plastic tweezers and disposable polyethylene gloves. The samples were not washed and not homogenized [12], they were dried to constant weight at $30-40^{\circ} \mathrm{C}$ for 48 hours. About $0.3 \mathrm{~g}$ of mosses were pelletized in press-forms. Then the samples were precisely weighed. Moss samples for short-term irradiation were heat-sealed in polyethylene foil bags, while the samples for long-term irradiation were packed in aluminum cups.

\section{SEM}

To increase the probabilities of seeing micro particles, which are expected to be in a small quantity (like cosmic dust), two moss samples (No. 8 Lesser

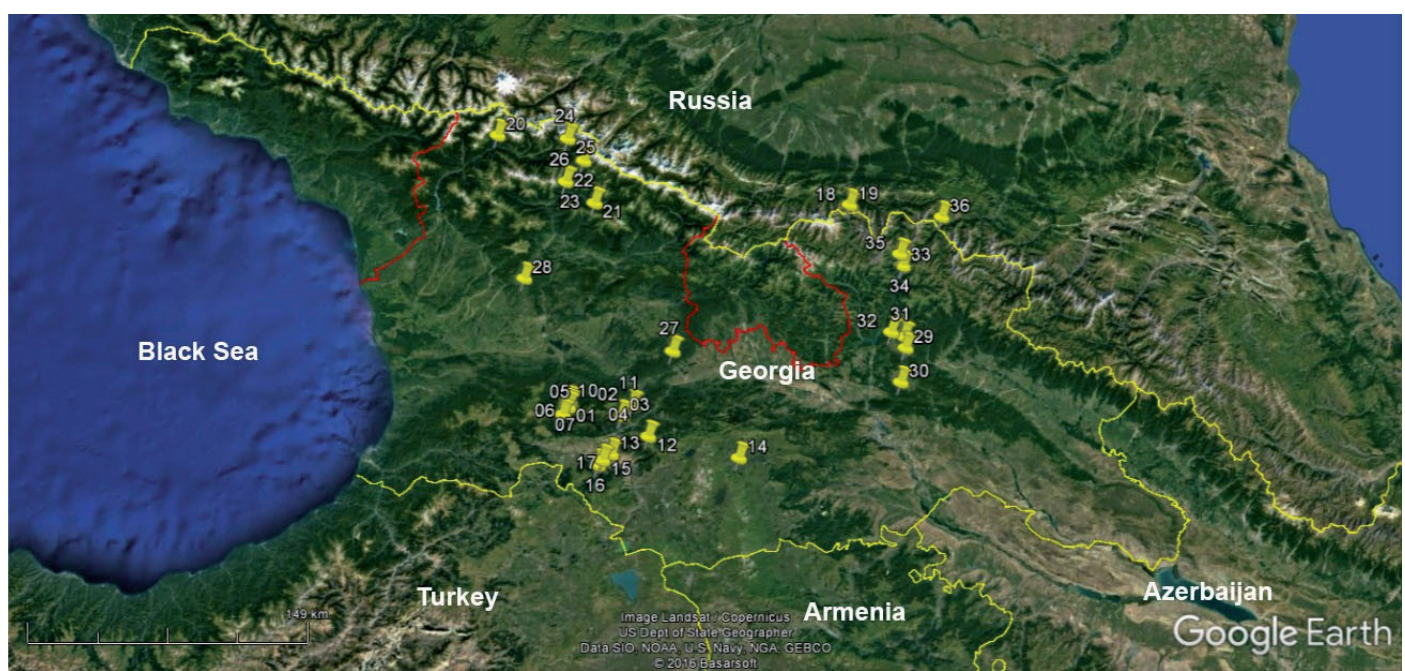

Fig. 1. Area of study showing sampling locations. 
Table 1. Concentrations of elements $(\mathrm{mg} / \mathrm{kg})$ determined by NAA for Georgia and Norway.

\begin{tabular}{|c|c|c|c|c|c|c|c|c|c|}
\hline \multirow{3}{*}{ Element } & \multirow{3}{*}{ Isotope } & \multirow{3}{*}{ Half life } & \multirow{3}{*}{$\begin{array}{l}\text { Gamma } \\
\text { peak ener- } \\
\text { gies }(\mathrm{keV})\end{array}$} & \multirow{2}{*}{\multicolumn{2}{|c|}{$\begin{array}{c}\text { Georgia } 2014 \\
n=16\end{array}$}} & \multirow{2}{*}{\multicolumn{2}{|c|}{$\begin{array}{c}\text { Georgia } 2015 \\
n=36\end{array}$}} & \multirow{2}{*}{\multicolumn{2}{|c|}{$\begin{array}{l}\text { Norway } \\
n=100\end{array}$}} \\
\hline & & & & & & & & & \\
\hline & & & & Median & Range & Median & Range & Median & Range \\
\hline $\mathrm{Na}$ & ${ }^{24} \mathrm{Na}$ & $14.7 \mathrm{~h}$ & $1,368.55$ & 721 & 268-1990 & 338.5 & $101-2,080$ & nd & nd \\
\hline $\mathrm{Mg}$ & ${ }^{27} \mathrm{Mg}$ & $9.5 \mathrm{~m}$ & $1,014.44$ & 4410 & $2720-11600$ & 2,380 & $1,380-6,300$ & 1730 & $940-2370$ \\
\hline $\mathrm{Al}$ & ${ }^{28} \mathrm{Al}$ & $2.2 \mathrm{~m}$ & $1,778.9$ & 5195 & $2450-20800$ & 2,955 & $759-12,600$ & 200 & $67-820$ \\
\hline $\mathrm{Cl}$ & ${ }^{38} \mathrm{Cl}$ & $37.2 \mathrm{~m}$ & $2,167.68$ & 225 & $140-465$ & 149.5 & $57.3-333$ & nd & nd \\
\hline $\mathrm{K}$ & ${ }^{42} \mathrm{~K}$ & $12.4 \mathrm{~h}$ & $1,524.6$ & 5875 & $3080-9040$ & 4,610 & $2,030-8,360$ & nd & nd \\
\hline $\mathrm{Ca}$ & ${ }^{49} \mathrm{Ca}$ & $8.7 \mathrm{~m}$ & $3,084.4$ & 11800 & $7140-15300$ & 6,530 & $4,880-10,900$ & 2820 & $1680-5490$ \\
\hline V & ${ }^{52} \mathrm{~V}$ & $3.8 \mathrm{~m}$ & $1,434.4$ & 11.8 & $6.2-54.0$ & 5.575 & $1.71-18.9$ & 0.92 & $0.39-5.1$ \\
\hline $\mathrm{Mn}$ & ${ }^{56} \mathrm{Mn}$ & $2.6 \mathrm{~h}$ & $1,810.7$ & 158 & $70-592$ & 109 & $21.7-525$ & 256 & $22-750$ \\
\hline $\mathrm{Fe}$ & ${ }^{59} \mathrm{Fe}$ & $44.5 \mathrm{~d}$ & $1,099.1$ & 3935 & $1640-14700$ & 2,000 & $404-11100$ & 209 & $77-1370$ \\
\hline $\mathrm{Zn}$ & ${ }^{65} \mathrm{Zn}$ & $244.0 \mathrm{~d}$ & $1,116.0$ & 38.1 & $17.3-68.7$ & 20.4 & $7.15-48.4$ & 26.5 & $7.9-173$ \\
\hline As & ${ }^{76} \mathrm{As}$ & $26.3 \mathrm{~h}$ & 559.1 & 0.88 & $0.33-2.87$ & 0.6935 & $0.176-7.55$ & 0.093 & $0.020-0.505$ \\
\hline $\mathrm{Br}$ & ${ }^{82} \mathrm{Br}$ & $35.3 \mathrm{~h}$ & 554.3 & 4.545 & $2.3-9.8$ & 5.145 & $2.33-7.45$ & 4.5 & $1.4-20.3$ \\
\hline Mo & ${ }^{99} \mathrm{Mo}$ & $66.0 \mathrm{~h}$ & 140.5 & 0.35 & $0.24-0.77$ & 0.286 & $0.174-0.894$ & 0.135 & $0.065-0.70$ \\
\hline $\mathrm{Cd}$ & ${ }^{115} \mathrm{Cd}$ & $53.5 \mathrm{~h}$ & 527.6 & 0.25 & $0.12-0.56$ & 0.175 & $0.0317-0.791$ & 0.058 & $0.025-0.171$ \\
\hline I & ${ }^{128} \mathrm{I}$ & $25.0 \mathrm{~m}$ & 442.9 & 2.795 & $1.3-5.1$ & 1.29 & $0.577-2.79$ & 2.5 & $0.6-41.7$ \\
\hline $\mathrm{La}$ & ${ }^{140} \mathrm{La}$ & $40.2 \mathrm{~h}$ & $1,596.2$ & 2.13 & $0.92-6.28$ & 1.615 & $0.342-12$ & 0.189 & $045-2.56$ \\
\hline $\mathrm{Sm}$ & ${ }^{153} \mathrm{Sm}$ & $46.7 \mathrm{~h}$ & 103.2 & 0.43 & $0.03-0.94$ & 0.182 & $0.0402-1.86$ & 0.33 & $0.05-1.34$ \\
\hline W & ${ }^{187} \mathrm{~W}$ & $23.9 \mathrm{~h}$ & 685.7 & 0.13 & $0.06-0.27$ & 0.10405 & $0.0485-0.597$ & 0.127 & $0.009-1.23$ \\
\hline $\mathrm{Au}$ & ${ }^{198} \mathrm{Au}$ & $2.7 \mathrm{~d}$ & 411.8 & 0.00091 & $\begin{array}{c}0.00031- \\
0.00225\end{array}$ & 0.0000403 & $\begin{array}{c}0.00000602- \\
0.000267\end{array}$ & nd & nd \\
\hline $\mathrm{U}$ & ${ }^{239} \mathrm{~Np}$ & $2.4 \mathrm{~d}$ & 228.2 & 0.19 & $0.08-0.50$ & 0.1075 & $0.0207-0.752$ & 0.015 & $0.001-0.138$ \\
\hline
\end{tabular}

Caucasus, Mescheti and No. 25 Greater Caucasus, Lower Svaneti) were specially prepared for scanning electron microscopy with energy-dispersive x-ray spectroscopy (SEM/EDX). To increase the amount of micro particles, moss samples were ground into fine powders in an agate mortar, then subjected to ultrasonic dispersing in a beaker. On the bottom of the beaker a powerful neodymium magnet of $35 \mathrm{~mm}$ diameter was attached to avoid the loss of magnetic particles. Afterward the particles were mounted on a double-sided adhesive coal tape.
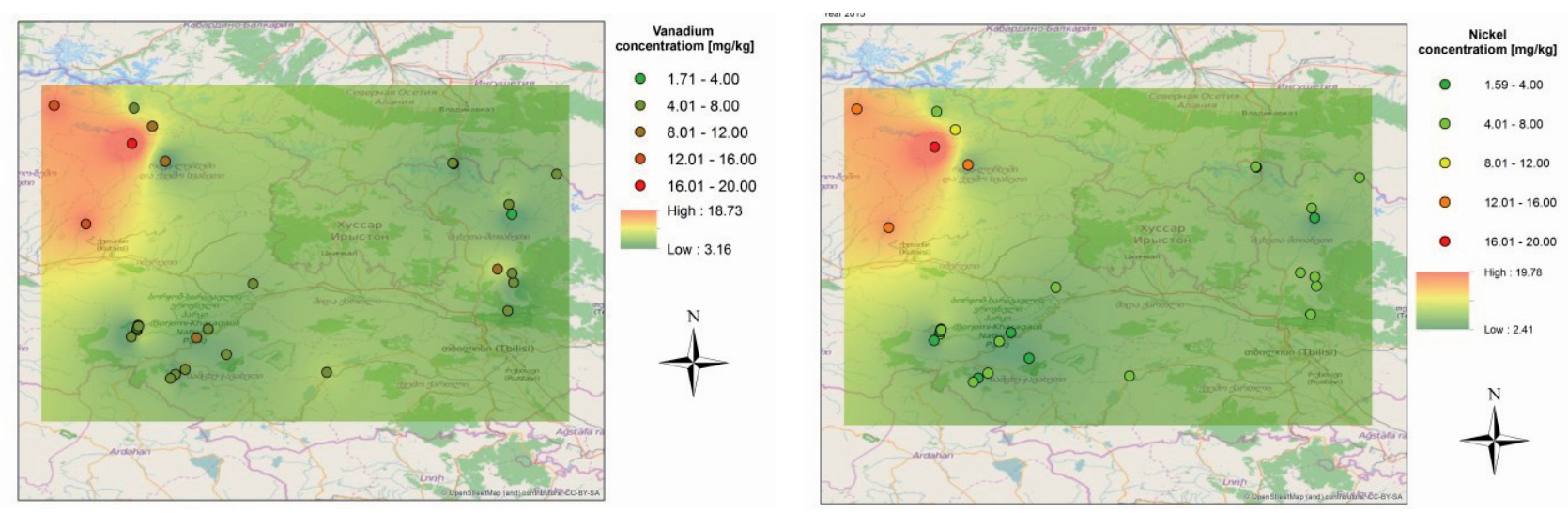

Fig. 2. Maps of the spatial distribution of concentrations of some heavy metals. 
Table 2. Matrix of rotated factor loadings $(n=36,20$ selected elements).

\begin{tabular}{|c|c|c|c|c|}
\hline & Factor 1 & Factor 2 & Factor 3 & Factor 4 \\
\hline $\mathrm{Ti}$ & 0.70 & 0.08 & 0.55 & 0.26 \\
\hline V & 0.83 & 0.12 & 0.44 & 0.17 \\
\hline $\mathrm{Cr}$ & 0.95 & 0.08 & 0.17 & 0.15 \\
\hline $\mathrm{Mn}$ & 0.38 & 0.12 & 0.02 & 0.49 \\
\hline $\mathrm{Fe}$ & 0.94 & 0.15 & 0.22 & 0.17 \\
\hline $\mathrm{Ni}$ & 0.90 & 0.15 & 0.33 & 0.15 \\
\hline Co & 0.95 & 0.13 & 0.14 & 0.17 \\
\hline $\mathrm{Zn}$ & 0.48 & 0.63 & -0.14 & 0.37 \\
\hline As & 0.95 & 0.11 & -0.07 & 0.01 \\
\hline $\mathrm{Br}$ & 0.31 & 0.03 & -0.32 & 0.72 \\
\hline Mo & 0.71 & 0.25 & 0.06 & 0.51 \\
\hline $\mathrm{Ag}$ & 0.22 & 0.00 & 0.84 & 0.01 \\
\hline $\mathrm{Cd}$ & 0.27 & 0.57 & -0.46 & 0.22 \\
\hline In & 0.02 & 0.77 & 0.12 & 0.02 \\
\hline $\mathrm{Sb}$ & 0.84 & 0.37 & -0.09 & 0.10 \\
\hline I & -0.14 & 0.26 & -0.03 & 0.85 \\
\hline $\mathrm{Au}$ & 0.29 & 0.79 & -0.04 & 0.22 \\
\hline $\mathrm{Hg}$ & 0.15 & -0.01 & 0.77 & -0.25 \\
\hline Th & 0.97 & 0.14 & 0.01 & 0.07 \\
\hline U & 0.97 & 0.15 & 0.02 & 0.11 \\
\hline $\begin{array}{c}\text { Exp. } \\
\text { variance }\end{array}$ & 14.65 & 2.47 & 2.66 & 2.60 \\
\hline Prp. Total & 0.54 & 0.09 & 0.10 & 0.10 \\
\hline
\end{tabular}

Analysis

$N A A$

ENAA of moss samples was carried out at the IBR-2 pulsed fast reactor (JINR, Dubna) as described elsewhere [13]. Concentrations of elements based on short-lived radionuclides were determined by irradiation for $30 \mathrm{~min}$. Gamma spectra of induced activity were measured twice, for $5 \mathrm{~min}$ after 5-7 min of decay. For determining the long-lived isotopes the samples were irradiated for 4 hours, repacked and then measured after 4-5 days of decay during $45 \mathrm{~min}$. The concentrations of 47 elements (Na, Mg, Al, Si, S, Cl, K, Ca, Sc, Ti, V, $\mathrm{Cr}, \mathrm{Mn}, \mathrm{Fe}, \mathrm{Ni}, \mathrm{Co}, \mathrm{Zn}, \mathrm{As}, \mathrm{Br}, \mathrm{Rb}, \mathrm{Sr}, \mathrm{Zr}, \mathrm{Mo}, \mathrm{Ag}, \mathrm{Cd}$, In, Sb, I, Ba, Cs, La, Ce, Nd, Sm, Eu, Tb, Dy, Tm, Yb, $\mathrm{Lu}, \mathrm{Hf}, \mathrm{Ta}, \mathrm{W}, \mathrm{Au}, \mathrm{Hg}$, Th, and $\mathrm{U}$ ) were determined based on relative method using the certified reference materials: trace elements in pine needles-1575a (NIST), trace elements in coal-1632c (NIST), Montana soil-2710 (NIST), and BCR-667 (Belgium).
Table 3. Factor scores.

\begin{tabular}{|c|c|c|c|c|}
\hline $\begin{array}{l}\text { Sampling } \\
\text { sites }\end{array}$ & Factor 1 & Factor 2 & Factor 3 & Factor 4 \\
\hline 1 & -0.27 & -0.19 & 1.43 & -0.96 \\
\hline 2 & -0.72 & 0.28 & 0.82 & -0.44 \\
\hline 3 & -0.45 & -0.14 & -0.36 & -0.99 \\
\hline 4 & 0.03 & 0.44 & 1.71 & -1.66 \\
\hline 5 & -0.49 & -0.63 & 0.99 & -0.72 \\
\hline 6 & -0.67 & -0.43 & 1.06 & 0.64 \\
\hline 7 & -0.72 & -0.62 & 0.39 & -1.60 \\
\hline 8 & -0.51 & 0.24 & -0.24 & 0.99 \\
\hline 9 & -0.66 & -0.24 & 1.24 & -0.24 \\
\hline 10 & -0.44 & -0.51 & -0.56 & 0.38 \\
\hline 11 & -0.50 & -0.51 & -0.79 & -0.11 \\
\hline 12 & -0.61 & -0.39 & -0.83 & 0.72 \\
\hline 13 & -0.40 & -0.38 & -0.41 & -0.63 \\
\hline 14 & 0.17 & -0.22 & 0.03 & 0.36 \\
\hline 15 & -0.19 & -0.94 & -0.74 & -1.16 \\
\hline 16 & 0.05 & -0.56 & -0.55 & -0.25 \\
\hline 17 & -0.11 & -1.27 & -0.33 & -0.07 \\
\hline 18 & -0.77 & 4.06 & -0.16 & -1.53 \\
\hline 19 & 0.22 & 0.72 & -1.46 & -0.32 \\
\hline 20 & 2.51 & -0.18 & -0.28 & -0.49 \\
\hline 21 & -0.10 & -0.54 & -0.89 & -0.58 \\
\hline 22 & 4.22 & 0.42 & 0.43 & 0.60 \\
\hline 23 & 2.13 & 0.02 & -0.93 & -0.46 \\
\hline 24 & 0.14 & 1.13 & 0.24 & -0.64 \\
\hline 25 & -0.25 & 0.85 & -0.11 & 0.49 \\
\hline 26 & 0.88 & 0.05 & 0.43 & -1.35 \\
\hline 27 & -0.49 & 2.68 & -1.44 & 2.22 \\
\hline 28 & 0.11 & 0.23 & 3.83 & 1.88 \\
\hline 29 & -0.37 & -0.21 & 0.08 & -0.05 \\
\hline 30 & -0.36 & 0.15 & -0.08 & 1.10 \\
\hline 31 & -0.50 & -0.05 & 0.12 & 1.41 \\
\hline 32 & 0.19 & -0.58 & 0.17 & 1.93 \\
\hline 33 & -0.42 & -0.86 & -0.64 & -0.12 \\
\hline 34 & -0.35 & -1.21 & -1.16 & 0.40 \\
\hline 35 & -0.07 & -0.71 & -0.42 & 1.18 \\
\hline 36 & -0.22 & 0.10 & -0.33 & 0.07 \\
\hline
\end{tabular}

For measuring sample activity in laboratory of NAA at IBR-2 reactor the automated registration and data processing system of gamma-ray spectra was 
used to conduct analysis of large sets of samples, to process large amounts of data, to increase productivity of analysis, to improve quality of results, to decrease the number of human errors, and to minimize human involvement in routine operations [14]. The system includes three high-purity Ge detectors, three sample changers, and control software with a database and processing programs.

\section{SEM}

The composition and morphology of the two samples from the 2015 collection (No. 8 Lesser Caucasus, Mescheti and No. 25 Greater Caucasus, Lower Svaneti) from the mountainous regions of Caucasus was examined using a Tescan Vega II scanning electron microscope with an energy-dispersive Drycool spectrometer at the Borok Geophysical Observatory (a branch of the Schmidt Institute of Physics of the Earth of the Russian Academy of Sciences). The separated mineral particles from samples dispersed by ultrasound were deposited on two-sided coal scotch. The investigations were carried out at an accelerating voltage of $20 \mathrm{Kv}$ and a current of $200 \mathrm{~Pa}$ (200 picoamperes, or 0.2 nanoamperes).

\section{Results and Discussion}

The results of the descriptive statistics are presented in Table 1 along with data on the Georgian collection of 2014 [10] and data on Norway [15], which is considered to be a pristine area of Europe. The comparison of results for 2014 and 2015 mosses shows that the median

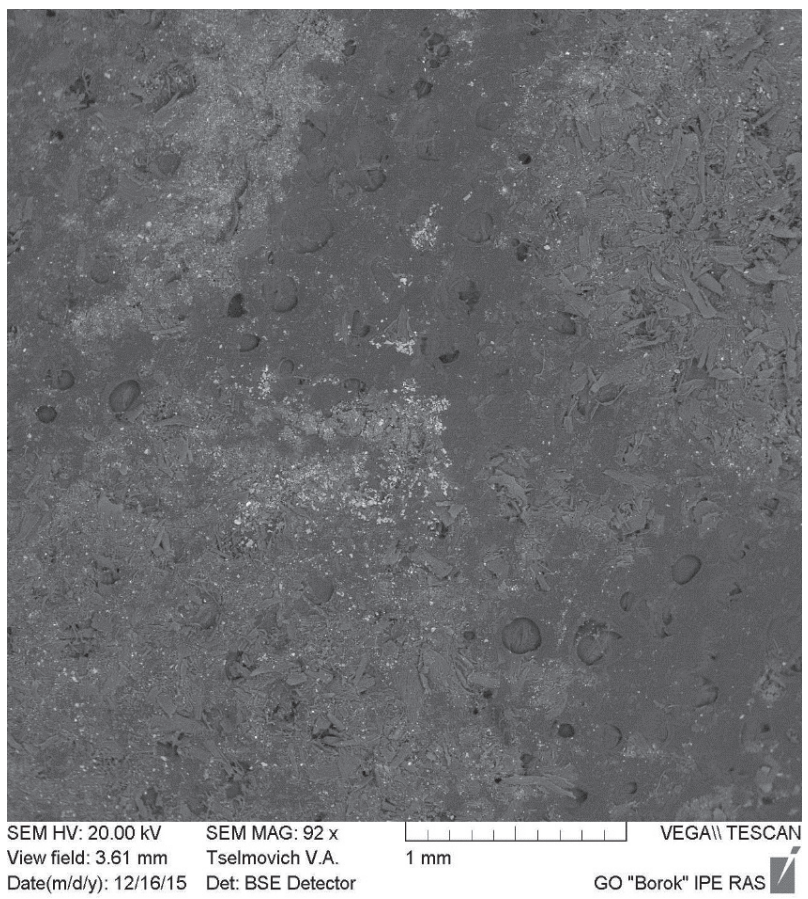

Fig. 3. Group of magnetic and paramagnetic particles, sample 8.

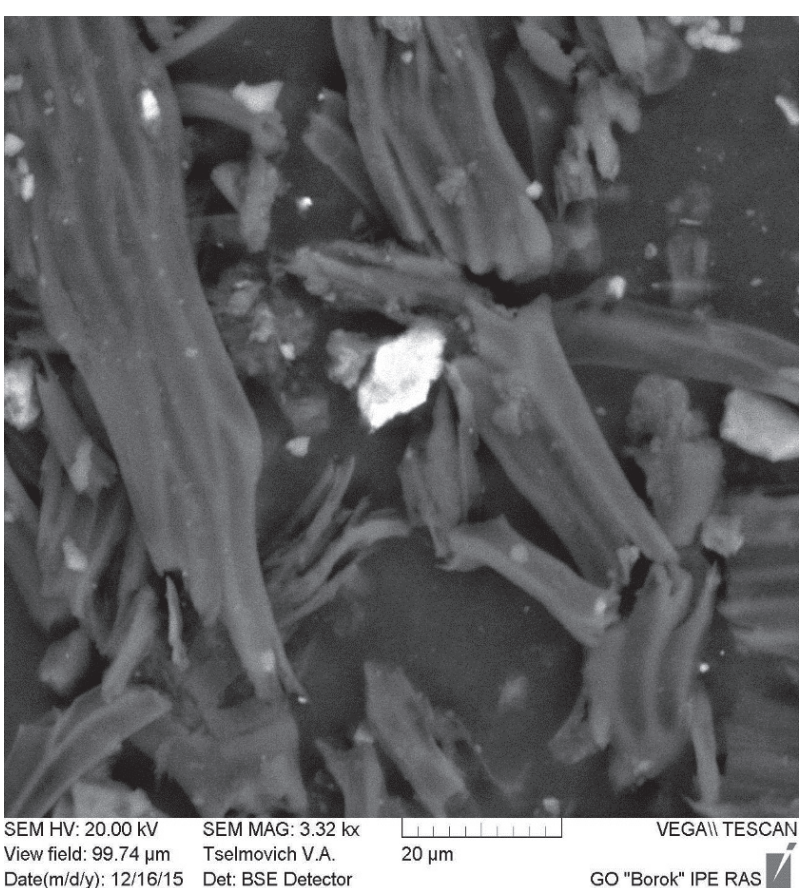

Fig. 4. The terrigenous particle of titanomagnetite, sample 8 .

concentrations of most elements decreased in 2015, which may be attributed to a larger number of averaging samples taken from points with different levels of contamination. A comparison of moss concentrations from Georgia and Norway showed increased values for most heavy metals ( $\mathrm{Mg}, \mathrm{Al}, \mathrm{V}, \mathrm{Fe}, \mathrm{As}, \mathrm{Mo}, \mathrm{Cd}, \mathrm{La}$, and $\mathrm{U})$ in the studied samples, which is due to the state of the industrial sector of Georgia. In mosses of Georgia the highest concentrations of arsenic were observed,

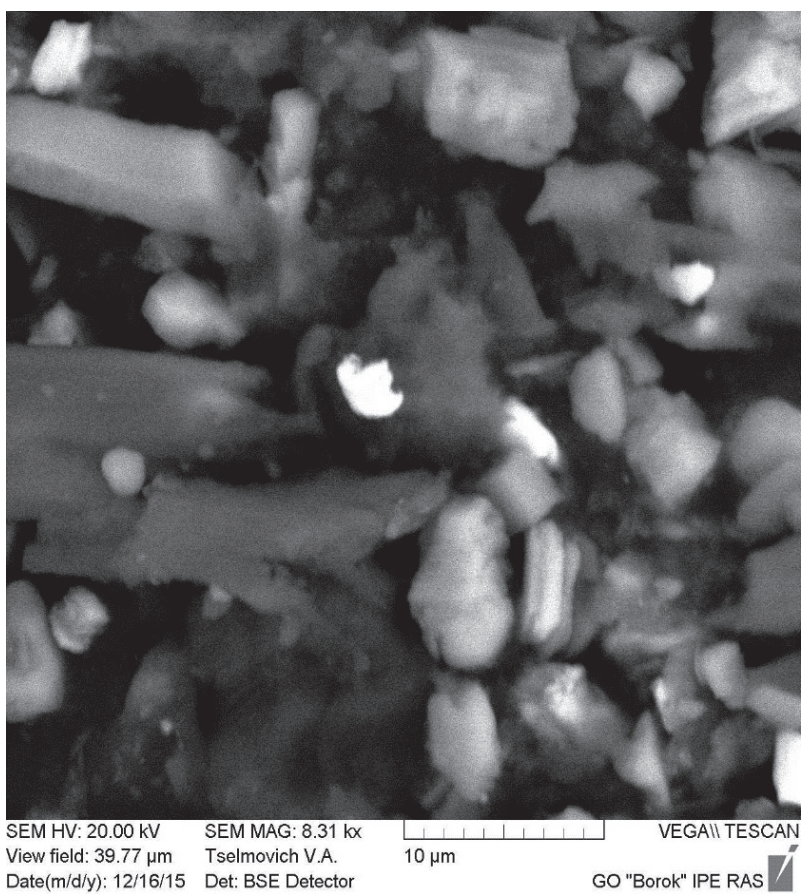

Fig. 5. Particles of native iron, size $3 \times 3 \mu \mathrm{m}$, sample 25 . 


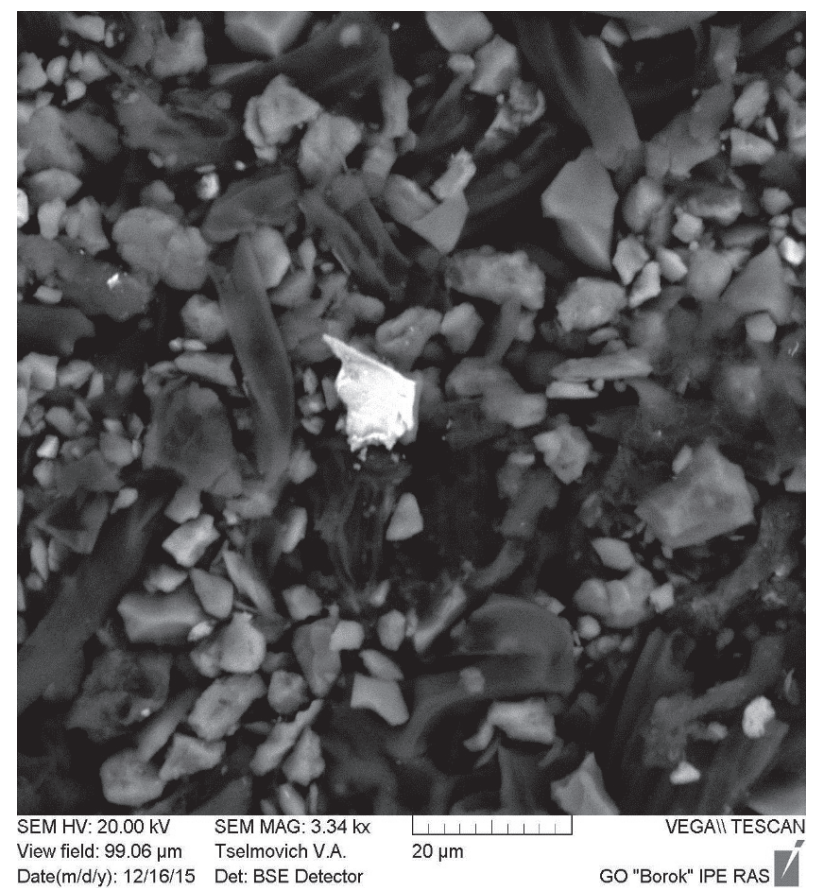

Fig. 6. FeCr alloy particle (intermetallic compound), size 10 x12 $\mu \mathrm{m}$, sample 25 .

which is apparently due to the poor condition of the old ore deposits of shut-down plants [5-7]. The higher concentrations of $\mathrm{I}$ and $\mathrm{Br}$ in moss from Norway are due to the proximity of the sea in this country, whereas moss in Georgia was mostly collected in the mountains.

Using the results of analysis of moss from the 2015 collection, we created maps of the spatial distribution

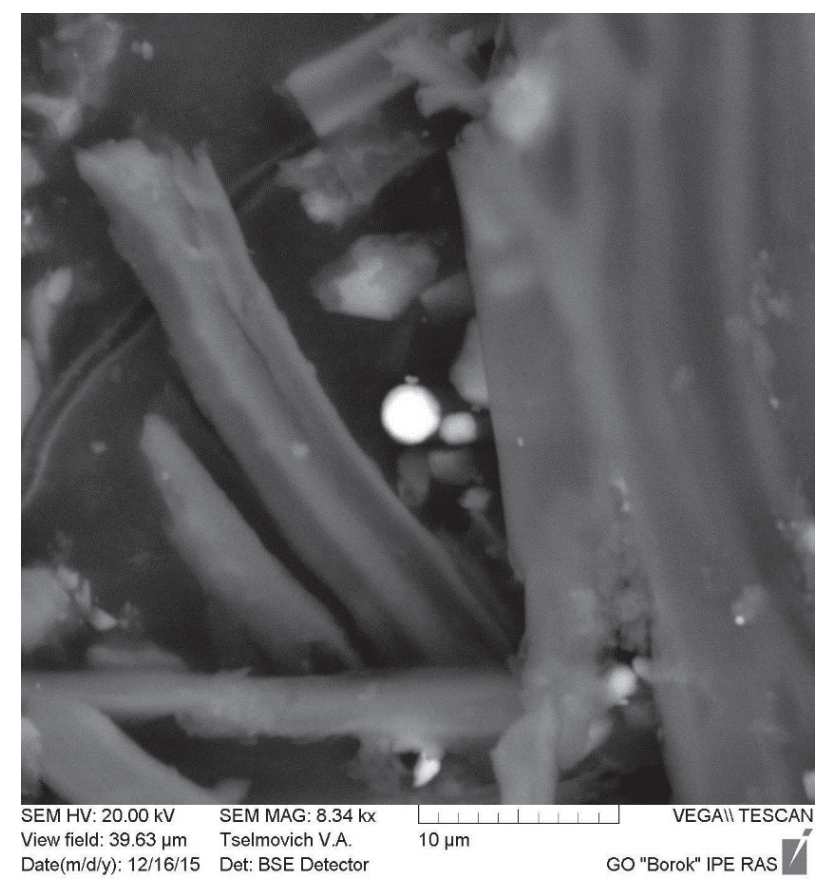

Fig. 7. Magnetite microsphere of cosmic dust, diameter $3 \mu \mathrm{m}$, sample 8 .

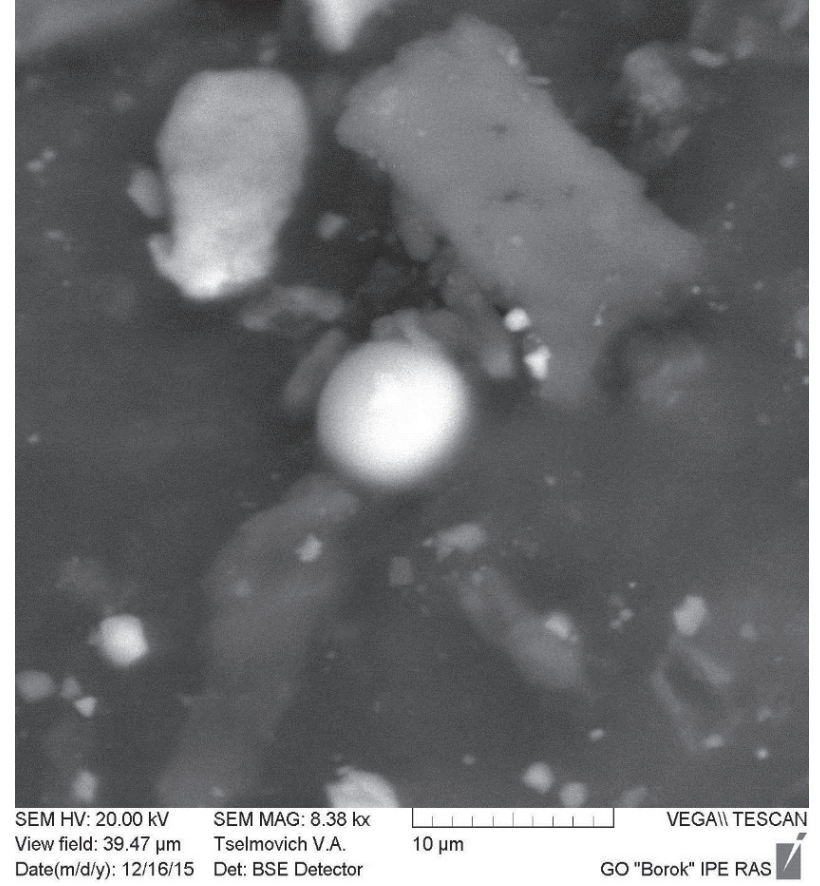

Fig. 8. Aluminosilicate microsphere, presumably cosmic dust, diameter $6 \mu \mathrm{m}$, sample 8 .

of concentrations of some heavy metals. The examples for vanadium (V) and nickel (Ni) are given in Fig. 2. As can be seen from these results, the northwest region of Georgia is characterized by a high level of pollution as the majority of metallurgical and mining industry enterprises - like the machine-building factory in Kutaisi, Zestaponi Ferroalloy Plant, and old mining of arsenic performed until 1990 (Ailama, Koruldashi) - the Chiatura mine complex and others are located there. For characterization of the pollution sources, the results were subjected to multivariate statistical analysis (factor analysis) using STATISTICA 12.6 softaware. To simplify the interpretation of the results, the rotation method of Varimax with Kaiser normalization was applied. The initial number of variables was reduced to four factors (Tables 2 and 3) [16].

- Factor 1: these elements obviously belong to light ( $\mathrm{Ti}$ (0.70), V (0.83), Cr (0.95)), and heavy (Fe (0.94), Ni (0.90), Co (0.95), As (0.95), Mo (0.71), Sb (0.84), Th (0.97), $\mathrm{U}(0.97))$ crust components.

- Factor 2: Zn (0.63), Cd (0,57), In (0.77), and Au (0.79) associated with maximal factor scores for sampling sites 18,24 , and 27 could be attributed to contamination from the road (18), Kutaisi metallurgical enterprises (24), and Zestaponi Ferroalloy Plant (27).

- Factor 3: $\mathrm{Ti}(0.55), \mathrm{Ag}(0.85)$, and $\mathrm{Hg}(0.77)$ associated with maximal factor scores for sampling sites $1,4,5$, 6,9 , and 28 most probably reflects contamination by local industrial enterprises.

- Factor 4: Br (0.72) and I (0.85) associated with sampling sites 6,8 , and 12 (western slopes of the Lesser Caucasus mountain range) and 27, 28, 30,31, 32, and 35 (eastern slopes of the Greater Caucasus) is definite- 
ly a marine factor due to the influence of their source - the Black Sea in the west and the Caspian Sea in the east.

Correlation analyses revealed most noticeable positive correlations of geochemically bounded elements such as $\mathrm{Al}$ and $\mathrm{V}(\mathrm{r}=0.94) ; \mathrm{Mg}$ and $\mathrm{V}(\mathrm{r}=0.89)$; Ti and $\mathrm{Al}(\mathrm{r}=0.89)$; Fe and $\mathrm{Cr}(\mathrm{r}=0.97)$; $\mathrm{W}$ and $\mathrm{Fe}(\mathrm{r}=0.89)$; As and $\mathrm{Sb}(\mathrm{r}=0.85)$; and $\mathrm{Th}$ and $\mathrm{U}(\mathrm{r}=0.99)$.

Figs 3-6, which were taken using the SEM technique, show terrigenous and anthropogenic particles. Fig. 3 shows many particles of magnetic and paramagnetic origin in light color while the silicate particles are grey. In images of sample No. 25 (Figs 5-6) FeCr alloy and native iron particles are observed. These particles can be characterized as cosmic dust. Diagnostics of cosmic particles against terrigenous and anthropogenic particles by composition and morphology is a rather complicated procedure due to the fact that particles of different origins can have a similar chemical composition and similar morphology. However, this has been worked out by many authors [17-20], whose experience and achievements have been used by us. In images of sample No. 8 (Figs 3-4) clastic titanomagnetite particles of volcanic origin are observed. Figs 7-8 demonstrate inclusion of beads of magnetite and aluminosilicate particles, presumably of cosmic origin.

\section{Conclusions}

The performed investigations show that moss biomonitoring of atmospheric deposition of heavy metals is an efficient technique for studying the environmental situation in Georgia. Elevated concentrations of heavy metals in comparison with the similar data for Norway are mainly characteristic of western regions of Georgia, where the main industrial enterprises and high-traffic roads are located. The results of multivariate statistical analysis confirm this conclusion. Microanalysis of moss samples shows the presence of particles of various origins: clastic, anthropogenic, and cosmogenic (cosmic dust).

\section{Acknowledgements}

This work was financially supported by a Georgia Shota Rustaveli National Science Foundation grant (No. AR/198/9-240/14, 28.04.2015-28.04.2017) "Investigation of atmospheric deposition of heavy metals in Georgia using moss biomonitoring and physical analytical techniques," and a grant from the Plenipotentiary of Georgia in JINR, Order No. 18 of 15.01.2016. Special thanks to Vladislav Svozilik for his help in constructing the maps.

\section{References}

1. Convention on Long-range Transboundary Air Pollution - CLRTAP. https://www.unece.org/fileadmin/DAM/env/ 1rtap/full\%20text/1998.Heavy.Metals.e.pdf (accessed on 23.03.17).

2. GYDESEN H., PILEGAARD K., RASMUSSEN L., RUHLING A. Moss Analyses Used as a Means of Surveying the Atmospheric Heavy Metal Deposition in Sweden, Denmark and Greenland in 1980. Report SNV PM 1670. National Swedish Environment Protection Board, Solna, 48, 1983.

3. ROSS H.B. On the use of mosses (Hylocomium splendens and Pleurozium schreberi) for estimating atmospheric trace metal deposition. Water, Air, and Soil Pollution, 50 (1), 63, 1990.

4. STEINNES E., RAMBÆK J.P., HAMSSEN J.E. Large scale multi-element survey of atmospheric deposition using naturally growing moss as biomonitor. Chemosphere, $\mathbf{2 5}$ (5), 735, 1992.

5. Georgia Country Environmental Analysis. World Bank Group Report number ACS13945. http://documents. worldbank.org/curated/en/293731468001755898/pdf/ ACS13945-WP-P147475-Box391501B-PUBLIC-6-26-15. pdf (accessed on 23.03.17).

6. CHIRAKADZE A., BUACHIDZE Z., KHOMERIKI I.O., GVAKHARIA V., STAMATELI M., CHAKVETADZE N., CHOKHELI M., TOSCANO W.A., CHIGOGIDZE K., GVERTSITELI L., BAGRATIONI N. Arsenic pollution of soils and morbidity prevalence in Racha-Lower Svaneti district of Georgia. International Journal of Global Warming, 10 (1), 92, 2016.

7. GURGULIANI I. Arsenic contamination in Georgia. Environment related security risks from old soviet legacy. http://www.osce.org/eea/110702?download=true (accessed on 23.03.17).

8. CARUSO B.S., MIRTSKHULAVA M., WIREMAN M., SCHROEDER W., KORNILOVICH B., GRIFFIN S. Effects of Manganese Mining on Water Quality in the Caucasus Mountains, Republic of Georgia. Mine Water and the Environment, 31 (1), 6, 2012.

9. SAFIROVA E. The Mineral Industry of Georgia. USGS, US Geological Survey Mineral Yearbook 2013, Advance Release, pp. 6, November 2015. https://minerals.usgs.gov/ minerals/pubs/country/2013/myb3-2013-gg.pdf (accessed on 23.03.17).

10. SHETEKAURI S., SHETEKAURI T., KVLIVIDZE A., CHALIGAVA O., KALABEGISHVILI T., KIRKESALI E.I., FRONTASYEVA M.V., CHEPURCHENKO O.E. Preliminary results of atmospheric deposition of major and trace elements in the Greater and Lesser Caucasus mountains studied by the moss technique and neutron activation analysis. Annali di Botanica, 5, 89, 2015.

11. Monitoring of Atmospheric Deposition of Heavy Metals, Nitrogen and Pops in Europe Using Bryophytes. Monitoring Manual 2015 Survey. ICP Vegetation. http://icpvegetation.ceh.ac.uk/publications/documents/ MossmonitoringMANUAL-2015-17.07.14.pdf (accessed on 23.03.17).

12. STEINNES E., HANSSEN J.E., RAMBÆK J.P., VOGT N.B., Atmospheric deposition of trace elements in Norway: temporal and spatial trends studied by moss analysis. Water, Air, and Soil Pollution, 74 (1), 121, 1994. 
13. FRONTASYEVA M.V. Neutron activation analysis for the Life Sciences. Physics of Particles and Nuclei, 42 (2), 332, 2011.

14. PAVLOV S.S., DMITRIEV A.YU., FRONTASYEVA M.V. Automation system for neutron activation analysis at the reactor IBR-2, Frank Laboratory of Neutron Physics, Joint Institute for Nuclear Research, Dubna, Russia. Journal of Radioanalytical and Nuclear Chemistry, 309 (1), 27, 2016.

15. STEINNES E., UGGERUD H.Th., PFAFFHUBER K.A., BERG T. Atmospheric deposition of heavy metals in Norway, National moss survey 2015. Norwegian Environmental Agency, M-594, 57, 2016.

16. JOLLIFFE I.T. Principal Component Analysis, $2^{\text {nd }}$ ed., Series: Springer Series in Statistics, Springer-Verlag New York, 150, 2002.

17. SHIJIE Z., HANCHANG P., ZHONG Y. Microanalytical study of some cosmic dust discovered in sea-floor sediments in China. NASA Technical Reports Server (NTRS). 1984. Available online: https://ntrs.nasa.gov/ search.jsp?R=19840018000 (accessed on 14.05.17).
18. GRACHEV A.F., KORCHAGIN O.A., KOLLMANN H.A., PECHERSKY D.M, TSELMOVICH V.A. A New Look at the Nature of the Transitional Layer at the K/T Boundary near Gams, Eastern Alps, Austria, and the Problem of the Mass Extinction of the Biota. Russian Journal of Earth Sciences, 7 (6), 1, 2005 [In Russian].

19. GRACHEV A.F., KORCHAGIN O.A., TSELMOVICH V.A., KOLLMANN Kh.A. Cosmic dust and micrometeorites in the transitional clay layer at the Cretaceous and Paleogene boundary in the Gams section (Eastern Alps): morphology and chemical composition. Physics of the Earth, 7, 42, 2008 [In Russian].

20. KORCHAGIN O.A. Metallic microspheres and microparticles in lower Cenomanian sediments of the Crimea: Evidence for the cosmic dust event. Doklady Earth Sciences 431 (2), 441, 2010 [in Russian]. 